\title{
De como o passado se faz presente
}

\author{
Mário Cláudio
}

\author{
Luiz Francisco Rebello, $O$ passado na minha \\ frente, Lisboa, Parceria António Maria \\ Pereira, 2004, 383 pp.
}

Afloração de um género de rara ocorrência na produção literária portuguesa, 0 passado na minha frente, de Luiz Francisco Rebello, constitui exemplo do que de melhor será capaz de proporcionar o memorialismo, isto em todos os tempos e lugares: a presentificação do pretérito que, ascendido às exigências de partilha, se transforma em capitulo de uma longa história comum. 0 escolho a vencer em tarefa de semelhante natureza, sempre que se achem em causa autoria e protagonismo lusos, reside no quantum satis de nostalgia, o qual entre nós se torna por regra muito mais quantum do que satis, apetite que, conformando um rosto antropológico, não cede qualquer espaço àquele grão de razoabilidade que autoriza o cosmopolitismo. Mas as memórias de Luiz Francisco Rebello, tão cidadão do Mundo como claro lisboeta, abrem a porta ao advento de algum lúcido quixotismo contra a plangência compulsiva das guitarras de Alcácer-Kibir.

Actor e testemunha da época que lhe coube, e que soberbamente reivindicou como sua, o narrador de 0 passado na minha frente manifesta-se tenaz inimigo dos circunstantes letárgicos, queremos dizer, não apenas dos que se retraem de intervir na cena onde se desenrolam os seus dramas, mas também desses que, acostando-se à moldura temporal que lhes cinge a biografia, se cegam para todas as outras, recusando-se a ver o passado "à sua frente", e persistindo nele, melancólica e irremediavelmente, atrás de si. Estamos pois com uma vida de vidas, o que significa que nos deparamos neste livro perante teias inúmeras, a da escrita, a da justiça que é também política, e a do teatro que, erguendo-se como afecto maior, atravessa a esfera de uma existência, convertendo-a em arte de palcos inúmeros, igual à que em suma corresponde, não só a um inteiro percurso, mas a uma teoria deles, e infinitamente.

Escrever sobre 0 passado à minha frente equivale a chamar a atenção para a curiosidade de ser, expressa no desejo de perpétua viagem que faz subir o itinerário pessoa ao plano de peregrinação, e o propõe como pretexto de comunitarismo, se não de verdadeiro tumulto moral. Há uma paixão vertebrante que rasga estas páginas, a da companheira de múltiplos momentos, nascida como Afrodite da espuma das vagas, e a elas recolhida, a fim de que a devolva a próxima preia-mar. Eu adivinho por isso que Virginia Woolf teria ouvido estas histórias num alerta singular, detectando nelas o remédio para a tragédia do monólogo, metamorfoseado em esplêndido lugar geométrico da impossibilidade do diálogo. Pois não será verdade que, arrimadas à solidão as falas da criatura que
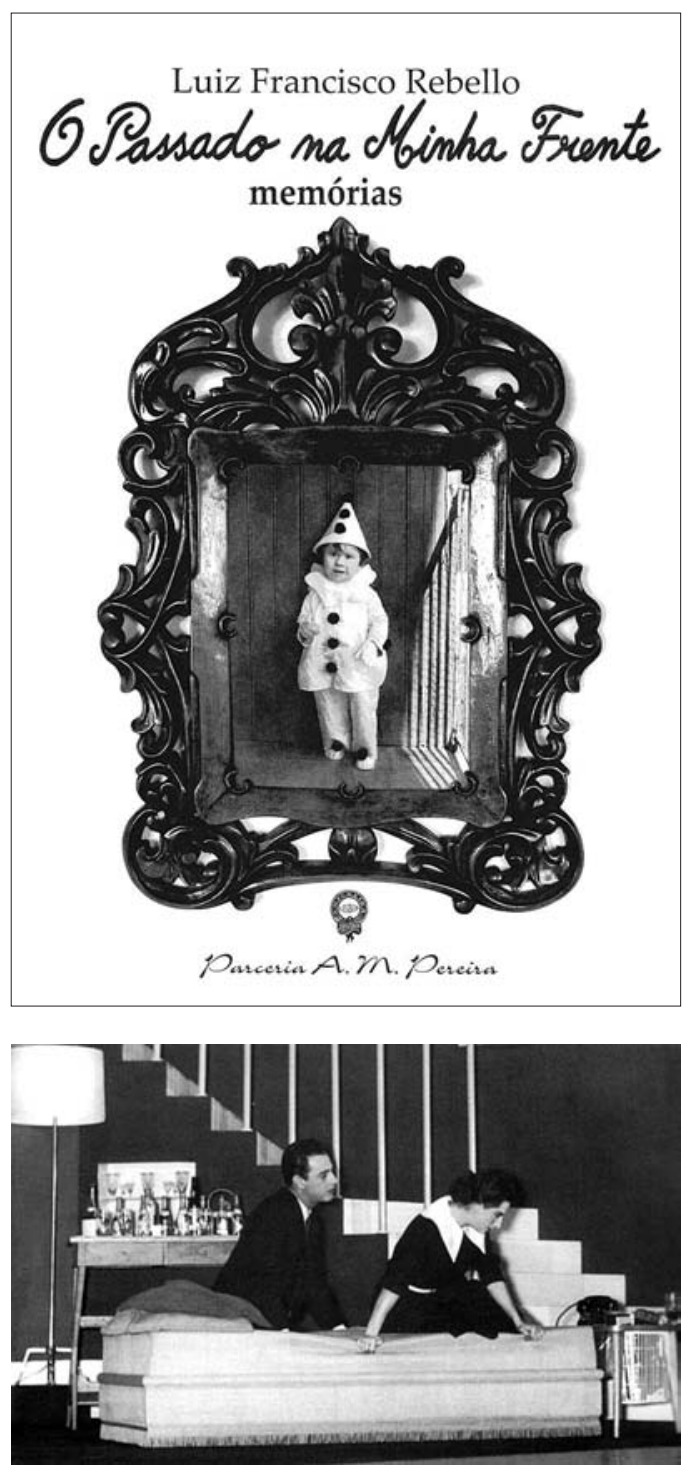

somos, se volvem mais únicas, quando mais iguais às daqueles com quem cruzamos os passos, e que desatinadamente ousamos amar?

0 compêndio de memórias de Luiz Francisco Rebello adiciona ao que pertence ao núcleo da individualidade 0 que conforma património de gentes, portuguesas e vivas, e sem o diminutivo que a elas apensou Carlos Queirós. Por obra de uma aventura assim, afloração como apontámos de um género de rara ocorrência na produção literária portuguesa, estamos prontos a um agora como só um sábio contador de lances nos pode legitimamente augurar. 